\title{
Symptoms Intensity and Distress Likert Scale
}

National Cancer Institute

\section{Source}

National Cancer Institute. Symptoms Intensity and Distress Likert Scale. NCI Thesaurus.

Code C159934.

A scale for the subjective scoring of a symptom's intensity and distress that ranges from 1: Slight to 5: Severe. 